\title{
When the gods are angry: volcanic crisis and eruption at Bali's great volcano
}

R. Gertisser ${ }^{1}$

F.M. Deegan ${ }^{2}$

V.R. Troll ${ }^{2}$

K. Preece ${ }^{3}$

${ }^{1}$ Keele University, School of Geography, Geology and the Environment, Keele, ST5 5BG, UK; r.gertisser@keele.ac.uk

${ }^{2}$ Uppsala University, Department of Earth Sciences, MPT, Villavägen 16, 75236 Uppsala, Sweden

${ }^{3}$ Scottish Universities Environmental Research Centre, East Kilbride, G75 0QF, UK

In November 2017, Bali's "great volcano", Gunung Agung, erupted for the first time since 1963 leading to the evacuation of nearly 150,000 people from a preliminary danger zone of $9-12 \mathrm{~km}$ radius from the summit. Since the phreatic onset of the eruption on 21 November, intermittent magmatic (Vulcanian) explosions continued to threaten local residents and disrupt air traffic to and from Indonesia's favourite tourist destination. Whereas the opening of the eruption seems to have been less energetic than the opening of the 1963 events, as of January 2018, the volcanic Alert Level for Agung remains at the highest level. Indeed, it remains unclear at this point what course the eruption will take and how long it will last, and the possibility remains that the eruption may turn more energetic in the months to come.

\section{Forces awakening on the "Isle of the Gods"}

When signs of volcanic unrest were noticed at Gunung Agung on Bali, the Isle of the Gods in the Hindu tradition, the volcano quickly caught the attention of volcanologists and the worldwide media. Nearly 1 million people live within a $30 \mathrm{~km}$ radius of Agung, which has great religious 
significance for the Balinese people. The 3,142 m high stratovolcano dominates the eastern part of Bali (Fig. 1), some distance away from the buzzing tourist resorts in the south of the island. Agung has been dormant for about half a century since its last eruption in 1963-64, during which almost 1,500 people were killed by pyroclastic flows and fast flowing volcanic mudflows (lahars). The 196364 eruption also had a measurable effect on Earth's climate, leading to a drop in global temperature of $0.1-0.4{ }^{\circ} \mathrm{C}$ due to the injection of sulphur dioxide into the stratosphere, as determined by Self and Rampino (see further reading). As Agung represents such a serious hazard for the people of Indonesia and beyond, it is perhaps unsurprising that the world's eye is focused on its apparent awakening. In this article, we summarise the recent unrest activity at Agung to date before offering potential volcanological explanations for its behaviour.

\section{Event timeline}

Volcanic earthquakes increased at Agung on 10 August 2017, prompting the Indonesian Center for Volcanology and Geological Hazard Mitigation (CVGHM) to raise the Alert Level to 2 (on a scale of 1-4). Both deep and shallow seismic tremors, interpreted to signal the rise of magma from deep inside the volcano, intensified throughout September 2017. This led to an increase of the Alert Level to 3 and the establishment of an exclusion zone on 18 September with a radius of $7.5 \mathrm{~km}$ from the summit in the N, SE and SSW sectors of the volcano, and $6 \mathrm{~km}$ in the other directions (Fig. 3).

After a surge in seismicity and the increased probability of an imminent eruption, the Alert Level was raised to its highest level of 4 on 22 September (Fig. 2) and the exclusion zone was expanded to $9 \mathrm{~km}$, and to $12 \mathrm{~km}$ in the SE, S and SW sectors of the volcano. By 4 October 2017, nearly 150,000 people (and several thousand farm animals) had been evacuated from the exclusion zone and distributed among hundreds of shelters. Throughout October, seismic tremors continued to fluctuate intensely, with more than 1,000 earthquakes on some days (Fig. 2). However, the exterior of the volcano still appeared quiet with only small gas plumes visible, rising $50-200 \mathrm{~m}$ above the summit. At the end of October, the number of earthquakes decreased dramatically to less than 100 earthquakes per day (Fig. 2), and the probability of an eruption was considered minimal. Although the seismic signals reduced in number and strength, as did the rate of deformation of the volcano, the recorded seismic activity remained above background level and therefore indicated magma movement at depth. The Indonesian authorities reacted to the volcano's changes by decreasing the 
Alert Level to 3 on 29 October and reducing the exclusion zone to a radius of $7.5 \mathrm{~km}$ from the summit in the NNE, SE, S and SW sectors of the volcano, and $6 \mathrm{~km}$ in the other directions

The long-awaited eruption at Agung eventually started on 21 November 2017, while the seismic activity was still at a low level. The eruption began with a phreatic (steam) explosion, which threw out pulverised old volcanic rock and generated an eruption column that rose $700 \mathrm{~m}$ above the volcano (Fig. 3a). Further explosions a few days later caused ash fall in areas southwest of the volcano and led to flight cancellations into and out of Bali's international airport. Incandescence in the crater on 25 November indicated the presence of fresh lava at the surface. On the same day, the first magmatic explosions occurred, which contained a fresh (juvenile) magmatic component, and ejected ash up to $4 \mathrm{~km}$ into the atmosphere. This event notably released detectable amounts of sulphur dioxide, whose atmospheric movement was monitored in real-time by satellite. Thin ash fall occurred in the areas to the south and west of Agung, and the international airport on the neighbouring island of Lombok was closed temporarily. On 27 November, the Alert Level was once again raised to the highest level (4), and the exclusion zone was expanded to an $8 \mathrm{~km}$ radius (10 km in the NNE, SE, S and SW sectors). In the weeks that followed, intermittent magmatic (Vulcanian) explosions occurred, with ash plumes rising up to $3 \mathrm{~km}$ above the crater rim and thin ash fall in surrounding areas (Fig. 3b). Images of the crater show that by 16 December 2017, about 20 million cubic metres of lava were extruded on the crater floor, filling approximately a third of the crater volume. Lahars, remobilising the newly fallen ash by heavy rains, were noted immediately after the first explosions on 21 November and continued throughout December and into January. Explosive events on 11 January (Fig. 3c) and 15 January 2018 produced ash plumes that rose up to $2.5 \mathrm{~km}$ above the volcano, causing thin ash fall in areas downwind of the volcano. As of 20 January, ash and steam plumes were persistently seen above the crater rim, high-frequency volcanic earthquakes dominated the seismic activity of Agung and the Alert Level remained the highest level.

The eruption of Agung continues to pose enormous challenges to the local authorities. The extent of the exclusion zone is continuously assessed by the Indonesian authorities based on the volcano's activity and, at the time of writing (January 2018), remains at a $6 \mathrm{~km}$ radius from the summit. Approximately 50,000 evacuees continue to be hosted in temporary shelters. The extended period of increased seismic activity without eruption from September to November 2017 led to growing pressure among people living on the slopes of Agung to re-enter the exclusion zone, thus increasing their vulnerability in case of an eruption. Even after the onset of the eruption and the sporadic 
Vulcanian explosions, many areas on the slopes of the volcano have only been affected by thin ash fall and lahars, whereas outside the immediate danger zone, life on Bali has continued largely as normal.

\section{Lessons learned}

For volcanologists, the volcanic crisis and eruption at Agung provides important lessons. We attribute the approximately 6-week-long seismic swarm in September and October 2017 to the injection of a new batch of magma from depth into the shallower magma storage zone beneath the volcano. Such a process is a potential trigger mechanism for an eruption, but after the initial increase in activity at Agung, the volcano calmed down again. Periods of volcanic unrest or seismic crises without immediate eruption occur frequently, as shown by recent events in the past few years at Santorini (Greece), Teide (Spain) and Tambora (Indonesia), amongst others. An important challenge for volcanologists will be to understand why the eruption started 3-4 weeks after the seismic activity had already significantly declined. We propose that in the weeks prior to the eruption onset, the pressure in the magma plumbing system gradually built up due to the injection of hot and possibly gas-rich basaltic magma into a relatively shallow and cool andesitic magma storage zone at a depth of only a few kilometres in the Earth's crust. This magma injection ultimately exceeded the confining pressure of the shallow-level magma reservoir and triggered the eruption. Similar dynamic magmatic processes were proposed by scientists to explain the last eruption of Agung in 1963-64, one of the most significant volcanic events of the twentieth century (see further reading). However, at present, it is not clear what course the current eruption will take and how long it will last. If we take the 1963-64 eruption as an example, as well as the few documented older historical eruptions in 1843, 1821 (?) and 1808, as well as eruptions in the Holocene geological record of Agung, the most likely scenario in the short term will be continued small to moderately explosive ash fall eruptions over Bali and the neighbouring islands. Continued extrusion of lava at the summit may eventually fill and overspill the summit crater, causing lava flows down the slopes of Agung. More significantly, the growth of the lava pile or dome in the summit crater may lead to more vigorous explosive activity through the build-up of gas pressure beneath a sticky, viscous lava plug. Such explosive activity frequently produces pyroclastic flows that are associated with the collapse of eruption fountains but can also be generated by gravitational collapse of the lava dome itself. Pyroclastic flows, which are fast moving, hot avalanches of volcanic rock and gas that rush down the 
flanks of the volcano at high speeds to distances of several kilometres from the summit, were mainly responsible for the almost 1,500 fatalities of the 1963-64 eruption. Establishing an exclusion zone around the volcano, as implemented by the Indonesian authorities, mitigates effectively against the most immediate risk to humans from pyroclastic flows as well as lahars, the latter of which are inevitably triggered by heavy precipitation during Indonesia's rainy season. Further away from the volcano, there is a possibility of minor volcanic ash fall, which can, depending on wind direction, lead to air travel disruptions. We ought to bear in mind that when Agung last erupted, the eruption continued for about a year. Whether the eruption that started in 2017 will develop into a major event as in 1963-64 remains to be seen. We will continue to watch the eruption closely.

\section{Suggestions for further reading}

Fontijn, K., Costa, F., Sutawidjaja, I., Newhall, C.G. \& Herrin, J.S., 2015. A 5000-year record of multiple highly explosive mafic eruptions from Gunung Agung (Bali, Indonesia): implications for eruption frequency and volcanic hazards. Bulletin of Volcanology, v.77:59, https://doi.org/10.1007/s00445-015-0943-x.

Global Volcanism Program, 2013. Agung (264020). In: Volcanoes of the World, v. 4.6.4. Venzke, E. (ed.). Smithsonian Institution. URL http://volcano. si.edu/volcano.cfm?vn=264020 [accessed 7 Jan 2018].

Self, S. \& King, A.J., 1996. Petrology and sulphur and chlorine emissions of the 1963 eruption of Gunung Agung, Bali, Indonesia. Bulletin of Volcanology, v.58, pp.263-285.

Self, S. \& Rampino, M., 2012. The 1963-1964 eruption of Agung volcano (Bali, Indonesia). Bulletin of Volcanology, v.74, pp.1521-1536.

Zen, M.T. \& Hadikusumo, D., 1964. Preliminary report on the 1963 eruption of Mt. Agung in Bali (Indonesia). Bulletin Volcanologique, v.27, pp.269-299. 


\section{Figures}

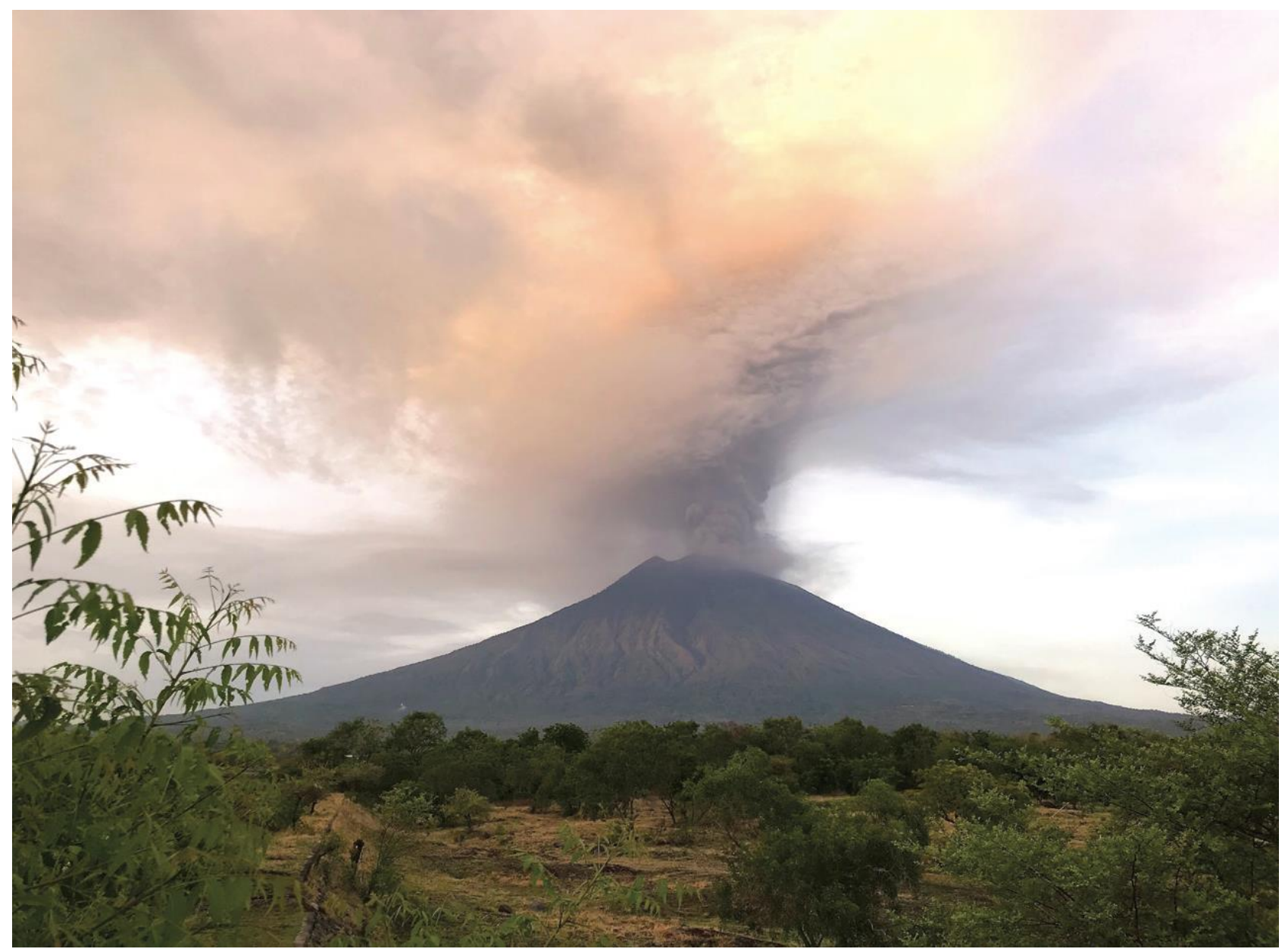

Fig. 1. Forces awakening on the 'Isle of the Gods': Mt Agung, 27 November 2017 (Photo: Michael W. Ishak, CC-BY-SA 4.0). 

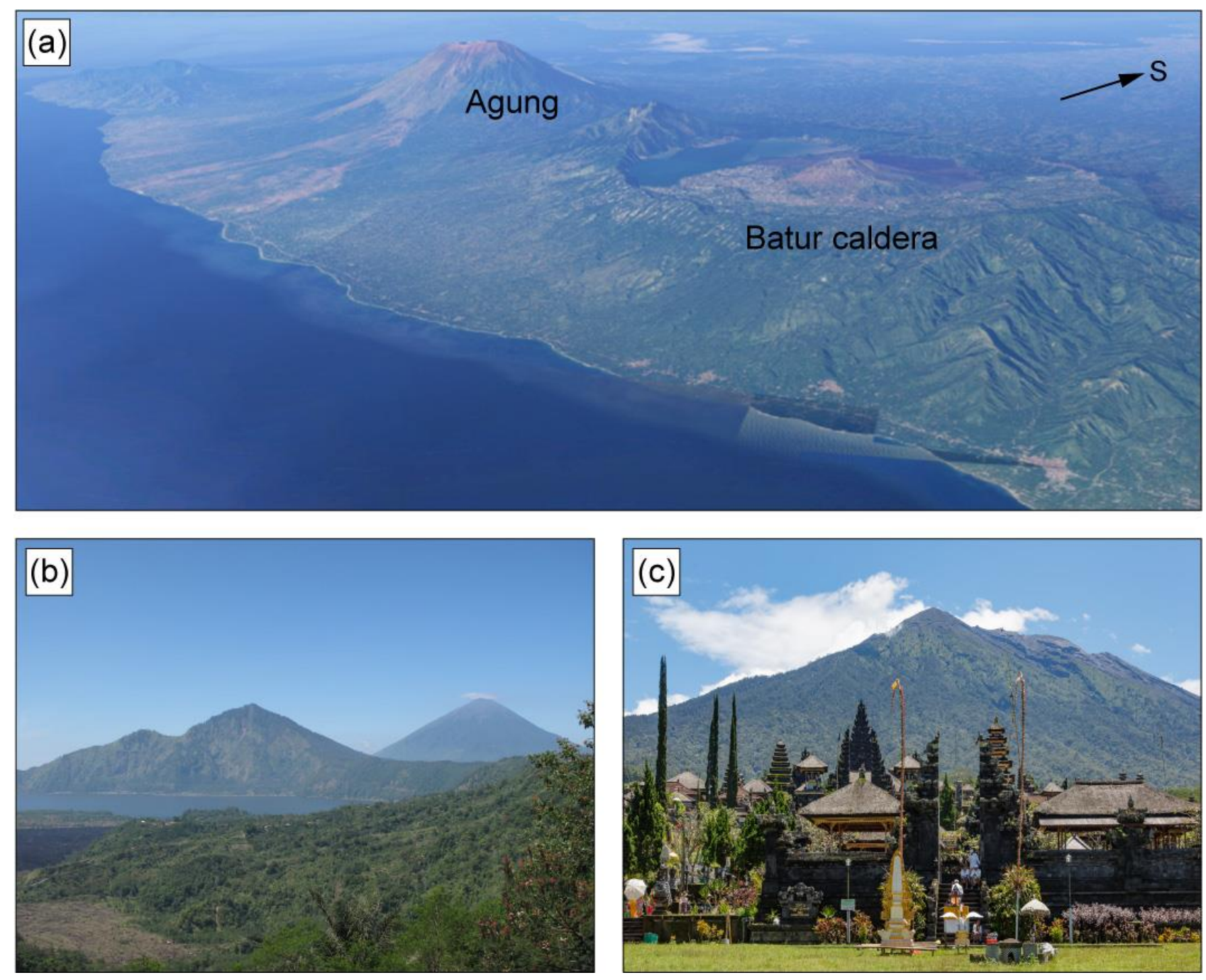

Fig. 2. (a) Oblique view of Gunung (means 'Mount' in Indonesian) Agung, the 3,142-m-high stratovolcano in eastern Bali. To the northwest of Agung, the huge caldera of Bali's other active volcano, Batur, is a reminder of the powerful nature of Indonesian volcanoes (image from Google Earth). (b) Batur caldera with Agung in the background. (c) The Mother Temple of Bali, Pura Besakih, on the southwestern slopes of Agung, which is considered the most important Hindu temple on Bali. Pura Besakih remained largely undamaged by the devastating eruption of Agung in 1963-64 (Photo: CEphoto, Uwe Arana, CC-BY-SA 3.0). 


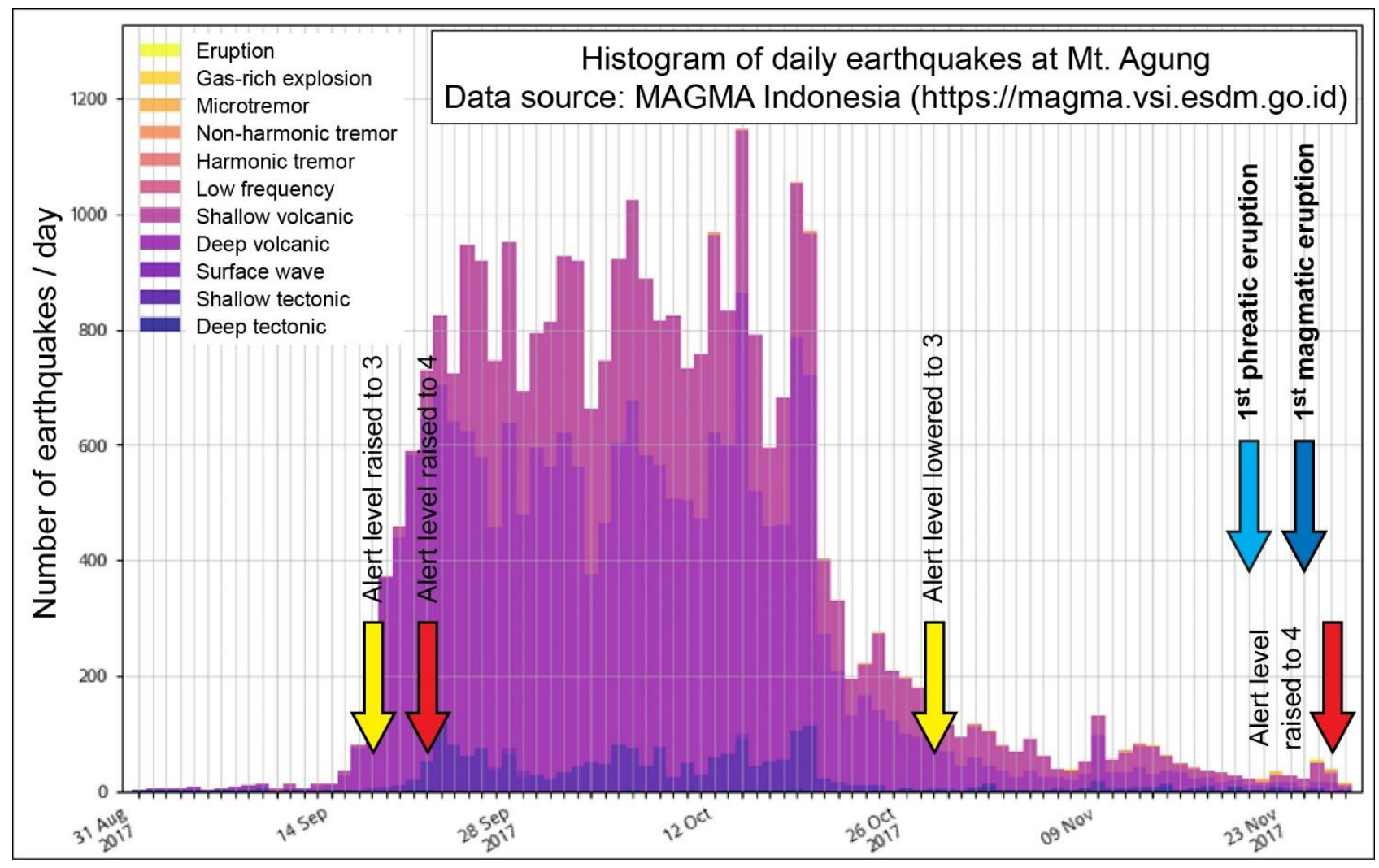

Fig. 3. Seismicity (number of earthquakes per day, colour coded according to earthquake type) at Agung in September, October and November 2017. Arrows indicate changes in the Alert Level imposed by the Indonesian authorities, the date of the first phreatic eruption (21 November), and the beginning of the magmatic eruption phase (25 November). Seismic activity above background level continued into January 2018 (Source: MAGMA Indonesia; https://magma.vsi.esdm.go.id/. Translation by Herlan Darmawan, Deutsches GeoForschungsZentrum Potsdam, Germany). 

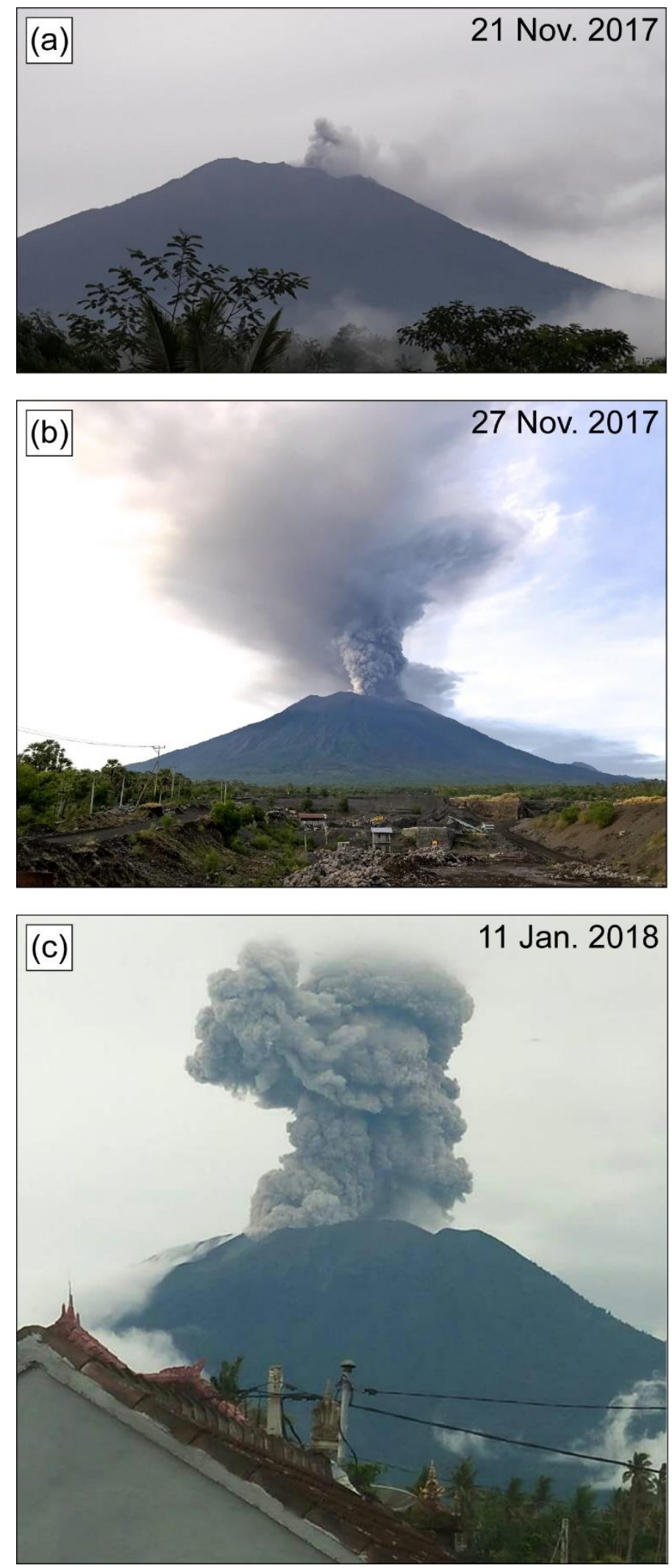

Fig. 4. (a) A phreatic explosion on 21 November 2017 signalled the beginning of the recent Agung eruption (Photo: MAGMA Indonesia; https://magma.vsi.esdm.go.id/). (b-c) Magmatic (Vulcanian) explosions at Agung on 27 November 2017 (Photo: Michael W. Ishak, CC-BY-SA 4.0) and 11 January 2018 (Photo: MAGMA Indonesia; https://magma.vsi.esdm.go.id/). 